\title{
TIME AND AGAIN
}

\author{
Reflections on the past.
}

\section{BY MOSHE SIPPER}

$\mathrm{T}$ he thing I hated most was when people told me that I wasn't to blame, because, after all, I was only seven years old when the 'unpleasantness' began. I hated that too, the way they always used some kind of euphemism. It was not 'unpleasantness', nor 'troubles at home', nor 'sad period in life', nor any of those other phrases I've heard over the years. There are no words to describe what happened.

For what would you call a father who rapes his daughter daily from the time she is five years old until she's thirteen? What kind of 'unpleasantness' comes to a halt only when a thirteen-year-old kills herself? How 'sad' is it when the monster who committed these atrocities walks away a free man through some legal loophole? Our language was not invented to encompass such acts.

And, despite what everyone has said over the years, I do blame myself. Very much so. I was only seven years old when it all began, but I was fifteen by the time it ended. Had I done anything at any point in between, perhaps when I was twelve, or thirteen, or fourteen, then my sister would still be alive today. If only I could go back ... I'd need just one instant, just a few seconds ...

That's what drove me to major in physics, and later on to do graduate work on the nature of time. That was quite a while ago. I'm now a full professor of physics, with some well-known papers on the subject of time. But I only published those so that I could get tenure and promotion. So that people would leave me alone to do what I really wanted: find a way to travel back in time.

Of course, I didn't talk about that much, least of all with my colleagues. As a physicist it doesn't hurt if you're considered eccentric, it maybe even helps, but being labelled downright crazy can get you kicked out of your field - and your job. And I needed my job, I needed the time it afforded me to study time.

Fairly quickly I realized that the past could

DNATURE.COM

Follow Futures:

y @NatureFutures

$f$ go.nature.com/mtoodm not be changed - at least not in my timeline. If I went back in time, my mere appearance, my very first breath in the past, would create a new branch in time - a new universe. Years ago I'd mentioned this to a psychologist I'd been dating and she had eyed me askance and said: "So you want to create universes, huh? Sounds like a God complex to me." the very day it had all begun, took one last unregretful look at my cluttered office - and vanished from this cursed universe.

Only to reappear, after a moment of disorientation, in a place I knew infamously well: our basement. A warm, fuzzy feeling filled my heart as I saw my old tricycle, the one I'd been given for my second birthday, rusting over in one corner. Success! I had travelled back in time. Then an icy hand seemed to grab my heart and twist it. I saw the thing on the floor next to the tricycle, looking for all the world like an innocent object but which to me was the epitome of evil: the dirty mattress.

In my shock I stumbled onto something and heard the sound of shattering glass. I looked down to find my mother's old make-up mirror lying there in pieces. Then I heard something that made my blood run cold.

"Hello cutie-pie, daddy's home."

The monster was in the house! And he would soon be taking my sister down here for the very first time. That dirty mattress was about to witness evil incarnate, and would do so for many years to come.

No, I shouted in my mind. Not in this universe! I thought I'd arrive with enough time to put my plan into action but apparently I had only moments to prepare. I scanned the basement quickly for something I could use as a weapon, perhaps a hammer, or maybe one of those
I stopped dating psychologists after that. In fact, I hardly dated any women at all. I have no delusions of grandeur whatsoever, no God complex. And I don't wish to 'create universes', plural. I wish to create one single universe in which my sister grows up to become the wonderful person she could and should have been.

In that universe the monster is, of course, dead.

And now, after all those years of burning the midnight oil (and often the four-, fiveand six-oclock-in-the-morning oil too), I had it. The irony is that the solution turned out to be fairly simple, and the time-travelling device wasn't some large vehicle à la H. G. Wells, but a small, wrist-worn gadget.

There was absolutely no hesitation on my part, even though I knew this was a one-way trip: I would remain forever in the new universe I was about to create. I set the device to bricks left over from when they'd redone the kitchen. I'll kill him with my bare hands if I have to, I thought, gazing down at my small hands.

Small?

Something clicked in my mind, a realization that should have come way back in that abandoned future. I quickly picked up a shard of broken mirror and looked into it.

Only to see my sister's face staring back at me.

I heard footsteps coming down the stairs. "Daddy's coming, cutie-pie."

I clenched my teeth as my small hands gripped the mirror shard tighter.

Moshe Sipper is a professor of computer science at Ben-Gurion University who also writes science fiction and fantasy stories. More of his work can be found at www.moshesipper.com. 